ASTROBIOLOGY

\section{Fungus survives simulated Mars}

A small percentage of fungal cells were still able to divide after exposure to Marslike conditions aboard the International Space Station.

Dried samples of the Antarctic-dwelling black fungi Cryomyces antarcticus and Cryomyces minteri, which live inside rocks, were exposed for 18 months to a simulated Martian atmosphere of $95 \%$ carbon dioxide, as well as high levels of ultraviolet and cosmic radiation. Silvano Onofri at the University of Tuscia in Viterbo, Italy, and his colleagues found that less than $10 \%$ of the samples divided and formed colonies after their return to Earth. However, up to twothirds of the cells remained intact and yielded stable DNA.

The findings could inform future searches for evidence of life on Mars, the authors say.

Astrobiology 15, 1052-1059 (2016)

\section{ANIMAL BEHAVIOUR}

\section{Colour signals octopus fight}

Octopuses use body colour and posture to communicate to others during aggressive encounters, suggesting that they are more social than previously thought.

Octopuses are considered to be more solitary animals than many squid or cuttlefish. David Scheel of Alaska Pacific University in Anchorage and his colleagues reviewed filmed interactions between pairs of Octopus tetricus off the coast of New South Wales, Australia. Octopuses were darker when they were about to fight an approaching animal and paler when they were set to flee. When dark in colour, the animals also changed their

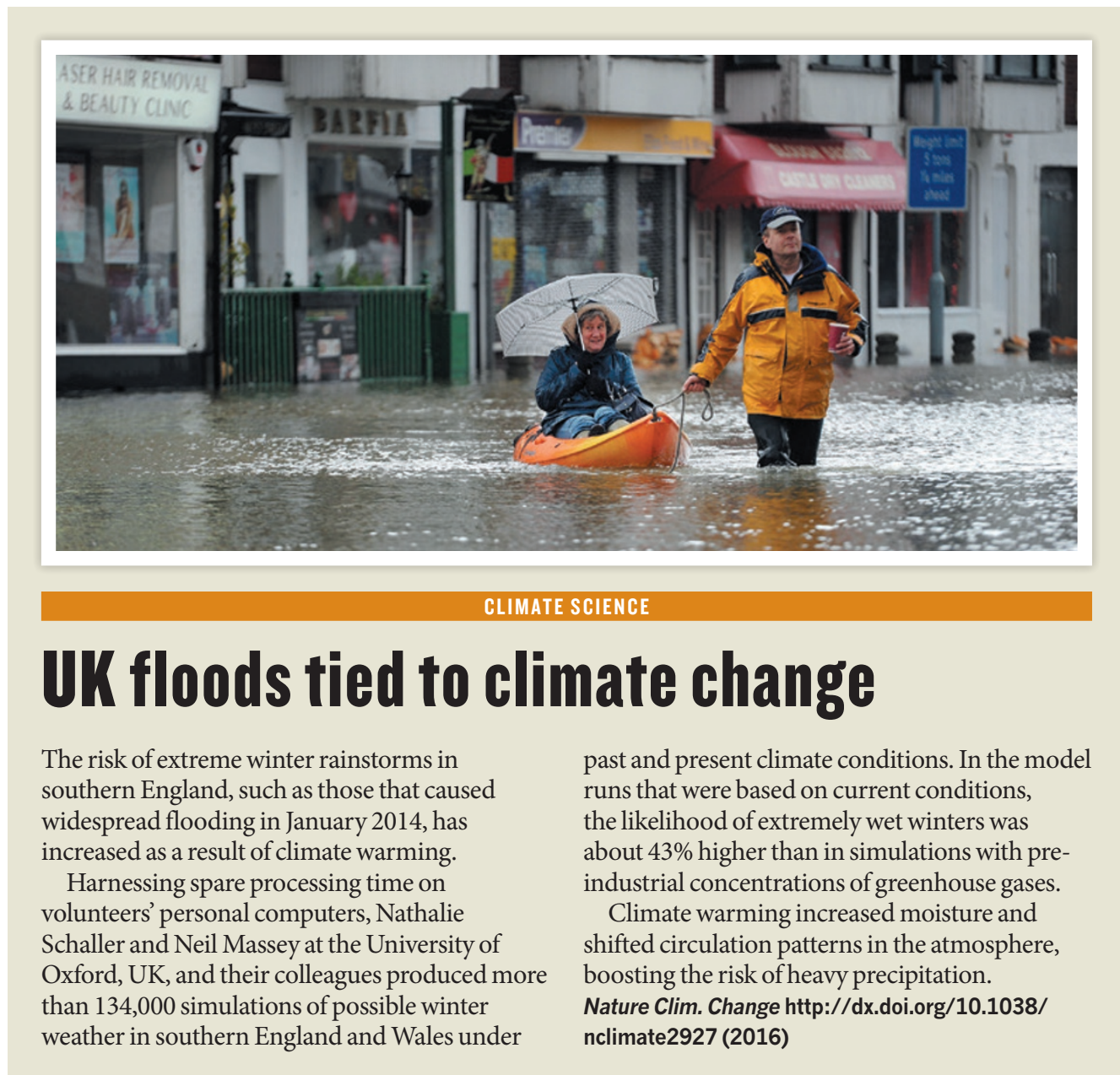

posture - by standing tall on higher ground and spreading the webs between their arms.

The octopuses could be using these signals to communicate their size, strength and willingness to fight to a rival, the authors say. Curr. Biol. http://doi.org/bb6f (2016)

\section{METABOLISM}

\section{On-off switch for obesity}

Genetically identical mice either become obese or stay lean because of differences in how a specific set of genes is regulated.

J. Andrew Pospisilik at the Max Planck Institute of Immunobiology and Epigenetics in Freiburg, Germany, and his colleagues studied mice with a mutation in the protein TRIM28, which has been linked to variation in body mass. The mice fell into two groups: those that grew obese and those of a normal weight, with the obese animals showing reduced expression of a network of genes involved in controlling weight.

The researchers then looked at data from obese and normalweight children, as well as from 13 pairs of identical twins - in which one twin was obese and the other was lean - and found similar patterns of gene expression to the TRIM28 mutant mice. Differences in maternal diet, communities of microorganisms or other environmental factors could be triggering the switch to obesity in mice, the authors say. Cell 164, 353-364 (2016)

\section{CONSERVATIOI}

\section{A map of threats from alien species}

Australia, the Americas and India are among the global hotspots where animals are most threatened by invasive species.

Ecologists debate the extent to which biodiversity is threatened by non-native species compared to threats from land-use change and other factors. To explore this, Céline Bellard at University College 